\title{
Directive Illocutionary Acts by the Characters in The Movie The Boss Baby
}

\author{
Palella Tias Rahmadanni \\ English Department, Faculty of Arts, Udayana University \\ [Email:palellatyas@gmail.com]
}

\begin{abstract}
Abstrak
Penelitian ini bertujuan untuk mendeskripsikan tipe-tipe tindakan bahasa illokusi yang direktif dan menganalisa kekuatan tindakan bahasa yang direktif yang diucapkan oleh para karakter. Data diambil dari sebuah film yang berjudul The Boss Baby yang menggunakan metode penelitian perpustakaan dan teknik dokumentasi, lalu dianalisa dengan metode kualitatif deskriptif. Ada dua teori yang digunakan untuk menjawab rumusan masalah. Pertama, teori directive illocutionary acts dari Searle dan Vanderveken (1985) untuk menganalisa rumusan masalah yang pertama. Kedua, teori directive illocutionary force dari Vanderveken (1990) yang digunakan untuk menjawab rumusan masalah yang kedua. Hasil analisis menunjukan bahwa ada enam tipe tindakan bahasa illokusi yang direktif, yaitu requesting, ordering, suggesting, warning, adjuring, and forbidding. Sedangkan kekuatan tindakan bahasa yang direktif mempunyai beberapa komponen yaitu the directive point, the mode of achievement, the propositional content, the preparatory condition, the sincerity condition, and the degree of strength of utterance.Kekuatan tindakan bahasa dikategorikan berhasil jika dapat memenuhi sетиа komponen tersebut.
\end{abstract}

Kata kunci: tindakan bahasa illokusi, kekuatan tindakan bahasa, direktif

\begin{abstract}
This thesis entitled Directive Illocutionary Acts of Characters in The Movie The Boss Baby aims to describe the types of directive illocutionary acts and analyze the directive illocutionary forces used by characters. The data were taken from the movie entitled The Boss Baby by applying library research method and documentation technique, then were analyzed by descriptive qualitative method. There are some theories used to answer this study's problems, which were divided into two main theories. First, theory of directive illocutionary acts proposed by Searle and Vanderveken (1985)which was used to analyze the first problem. Second, theory of directive illocutionary force proposed by Vanderveken (1990) which was used to answer the second problem. The study shows that there are 6 types of directive illocutionary acts; they are requesting, ordering, suggesting, warning, adjuring, and forbidding. Whereas the illocutionary force of directive illocutionary act has the directive point, the mode of achievement, the propositional content, the preparatory condition, the sincerity condition, and the degree of strength of utterance. Illocutionary force will be considered successful or felicitous if it fulfils all components.
\end{abstract}


Keywords: illocutionary acts, illocutionary force, directive.

\section{Background of the Study}

Language plays a crucial role in human life since it is the main tool to communicate with one another. When people use language in a conversation, they will produce some utterances to convey ideas through their speech.This phenomenon in language is generally called a speech act; action performed via language (Yule, 1996).

Speech act is not only the matter of the words which are uttered by the speaker, but it also relates to the speaker's intentions to the hearers (Bach, 1994:1)..

Movie is one medium that reflects the human social life. To make it easier for the hearer(s) to understand what the speakers says, a movie usually provides subtitles. One of the important aspects mostly occurring in movie is the dialogue (conversation) among the characters. The characters speak with one another and there will be directive illocutionary acts.

The Boss Baby is one of the animated movies produced by DreamWorks Animation. Its genres are comedy, fantasy, and family movie. The Boss Baby premiered at the Miami International Film Festival on March 12, 2017, and was released by 20th Century Fox on March 31, 2017. At the 75th Golden Globe Awards, the movie received a nomination for Best Animated Feature Film.

\section{Problems of the Study}

a) What types of directive illocutionary acts are performed by the characters in The Boss Baby movie?

b) What directive illocutionary forces used by characters are found in The Boss Baby movie?

\section{Aims of the Study}

a) To describe the types of directive illocutionary acts performed by the characters in The Boss Baby movie.

b) To analyze the directive illocutionary forces used by characters found in The Boss Baby movie.

\section{4. $\quad$ Research Method}

Research method is a process and procedure of how people approach the problem and seek answer.It covers four important points, namely data source, method and technique of collecting data, method and technique of analyzing data, and method and technique of presenting analysis.

\subsection{Data Source}

The primary source of this study is the speech acts produced by the characters in the movie The Boss Baby . Especially, for the main data, the speech acts produced by Tim's character are used.The movie was used as the data because there were many directive illocutionary acts found. This indicates many directive illocutionary acts found so it was relevant to the topic of this study.

\subsection{Method and Technique of Collecting Data}

The documentation method was used to collect the data. The data were collected through some steps. First, The Boss Baby movie and its script were downloaded

fromhttps://moviescouch.com/movie/the boss-baby-2017-movie-free-downloadhd-720p-bluray/. Second, the movie The Boss Baby was watched for several times to comprehend the utterances. Finally, the utterances spoken by the characters belong to directive illocutionary acts were identified. 


\subsection{Method and Technique of Analyzing Data}

This study used descriptive qualitative method to analyze the data. The data analysis consisted of three streams of activity: data reductionwas selecting and simplifying the data of the characters' utterances that belong to types of directive illocutionary acts so that there was no unimportant locution included in the data; the data displaypresented in the form of utterances or texts; and conclusion drawing and verification was describing and interpreting the data so that the conclusions and verifications of the directive illocutionary acts and force by the characters can be drawn.

\subsection{Method and Technique of Presenting the Result of Data Analysis}

This study used informal and formal methods in presenting the data analysis. This step was about presenting the data in words in the form of dialogue. Besides, this study used some pictures to help understand the situation when the utterances were uttered by the speaker.

\section{Result and Discussion}

This section discusses the directive illocutionary forces used by characters which are analyzed based on the six components of Vanderveken's theory of speech act.

\subsection{Preliminary}

The utterances were classified based on their types of directive illocutionary act proposed by Searle and Vanderveken (1985). Besides, it discusses the directive illocutionary forces used by characters which are analyzed based on the six components of Vanderveken's theory of speech act.

\subsection{The Analysis of Type of Illocutionary Acts and Force}

There are some types of directiveillocutionary acts found in character's utterances, they are requesting, ordering, suggesting, warning, adjuring, and forbidding. The description of each type is as follows:

\subsubsection{Request}

A request is a directive illocutionary act that allows the option of refusal (Vanderveken, 1990:189).

\section{Data}

Father : "It's Take Your Kid to Work Day! And you're the kid".

Tim : "Really?"

Father : "Really".

Tim : "Can the baby come, too?"

Mom : "I don't see why not".

Tim : "Yes! Yes, yes, yes!"

$$
\text { "Yeah!" }
$$

Based on the data, the interaction happens between Tim as a son and father and mom as his parents. Tim's parents wake him up to tell him that he was officially un-grounded and they invited him to The Take Your Kid to Work Day in Puppy Co. Tim asked his parents toallow the baby to come too with them. Based on the synopsis, the speaker performs directive with the illocutionary force of requesting. In this case, the speaker attempts to request his parents to allow the baby to come too.The speaker applied the formulaic structure of requesting with the use of the modal 'can' followed by the pronoun 'the baby' and the action that is 'come'. By performing requesting, the speaker attempted to minimize the imposition, hence, his utterance sounds more polite.

Its illocutionary force towards the hearers' responses is described as follows: 
a. The point of the directive illocution of the utterancecan the baby come, too? is the speaker (Tim) wants the hearers (his parent) to do something

b. The mode of achievement of the utterance shows the speaker excitedly requests for their permission to allow the baby to come too, as can be seen in his utterance can the baby come, too?

c. The propositional content of the utterance is the hearer accept his request by saying I don't see why not

d. The preparatory condition of the utterance is the speaker presupposes that the hearers are capable of fulfilling what the speaker wants because Tim and the baby have already shown their efforts to pretend to be actual brothers who loved each other and it makes their parents convinced

e. The sincerity of condition of the utterance shows that the speakerexpresses his desire that his parents will allow the baby to come too with them, as can be seen by his excited expression

f. The degree of strength of the utterance shows the speaker's seriousness to get the hearers to do something for him. He is so excited when he requested something to his parents.

Illocutionary force is successful because it fulfils all components. The purpose of requesting is to politely ask something or someone to do something and the hearers accepted his request by saying I don't see why not.

\subsubsection{Order}

Ordering is used to ask for something to be done (Vanderveken, 1990:194).

\section{Data}

Father : "Smile!"

Tim : "Smile for the camera."
The baby: "It makes me feel weak".

Tim and the baby pretended to be actual brothers who loved each other. They tried to do something together. For instance, Tim put a sailor shirt on the baby. Unexpectedly, their mother had another sailor shirt for him so they would look like good brothers. But actually they were not like that. At that moment, their father wantedto take some photos of them. The baby looked like unhappy and Tim ordered him to smile for the camera so they seemed to have a close relationship. In this case, Tim orders the baby to smile for the camera. His utterance is typified by the use of imperative form. Imperative sentences often appear to be missing subjects and use a verb to begin the sentence. For this case, the utterance uses a full-stop (.) as the final punctuation. Hence, it is included into the illocutionary force of ordering.

Its illocutionary force towards the hearers' responses is as described below:

a. The point of the directive illocution of the utterancesmile for the camera is that the speaker (Tim) asks the hearer (the baby) to do something

b. The mode of achievement of the utterance shows that the speaker requests the hearer to smile for the camera; it is proven by his utterance smile for the camera

c. The propositional content of the utterance is that the hearer has to smile but he does not do that instead he says it makes me feel weak

d. The preparatory condition of the utterance is the speaker presupposes that the hearer is not capable of doing what the speaker's want. It can be seen when in the first picture's section, the hearer has already shown his dislike expression.

e. The sincerity of condition of the utterance shows that the speaker 
expresses his hope that the hearer will smile for the camera although he is forced to do that. Whereas the speaker has already exemplifiedhow to smile. But in fact, the baby does not do that

f. The degree of strength of the utterance shows the speaker's seriousness to get the hearer to do something for him. It can be seen from his expression that expresses his worry if the baby does not smile for the camera so it can thwart their plan. Besides, the speaker tries to pull the hearer's lips for smiling.

Illocutionary force is unsuccessful because it does not fulfill all components; they are the propositional content and the preparatory condition.

\subsubsection{Suggest}

To suggest is just to make a weak attempt to get someone to do something (Vanderveken, 1990:195).

\section{Data}

Tim : "Hello! It's time for my three stories, five hugs, and special song!"

After a while

Tim : “How about one story... three hugs, and my special song?"

Tim : "Mom?Dad?"

Tim : "Hey"

Tim: "What happened to bedtime?"

Phone is ringing

Father : "We'll have it on Monday, Mr. Francis."

Mom : "Don't cry! Don't cry."

It was a time for bedtime; Tim organized his bed and put three book stories on his side. He was calling his parents and ready for his three stories, five hugs, and special song. But after waiting for a while, his parents did not come to his bedroom. Because of this, he offered an idea to his parents to give him only one story, three hugs, and his special song. Tim uses the phrase "how about" in giving suggestion to his parents. Based on the context, Tim's utterance is classified as directives and the illocutionary force performed is suggesting. It is clear since Tim proposes an offer to his parents to make a weak attempt so his parents can do it.

Its illocutionary force towards the hearers' responses isas described below:

a. The point of the directive illocution of the utterance how about one story... three hugs, and my special song?is that the speaker (Tim) attempts to get the hearers (his parents) to do something

b. The mode of achievement of the utterance shows that the speaker diminishes what he wants from the hearers by saying how about one story... three hugs, and my special song?

c. The propositional content of the utterance is that the hearers have to do what the speaker's wants because he has diminished what he wants but his parents still do not do that. It shows in the scene that the hearers do not come to his room

d. The preparatory condition of the utterance is that the speaker presupposes that the hearers are not capable of fulfilling what Tim's wants although he has diminished it because his parents did not come to his bedroom. Since he called his parents for the first time, they still did not come to his room

e. The sincerity of condition of the utterance shows that the speakerexpresses his hope and at the same time he actually has a doubt that the hearers will not come to his bedroom and do not do what Tim offers to them because he thinks that his parents are too busy to take care of the baby. It can be seen by his 
doubt expression and he weakens the tone of his voice

f. The degree of strength of the utterance shows the speaker's doubt to get a bad response from the hearers. It can be seen by his expression that expresses a feeling of despair because actually he has called them twice to remind their Tim's time but his parents did not come to fulfill his wants.

Illocutionary force is unsuccessful because it does not fulfill all components; they are the propositional content and the preparatory condition.

\subsubsection{Warn}

Warning is performed to make someone realize the possible danger or problem especially in the future (Vanderveken, 1990:197).

\section{Data}

Mom :"What's going on in here?"

Tim :" I'm just feeding the baby.

Tim : "They're watching."

Tim : "Choo-choo".

Finally, the baby eat forcefully what Tim fed to him

Mom : "Okay"

The participants are mom, father, Tim, and the baby.Tim pretended to be a good brother for the baby. He did anything to convince his parents that they were actual brothers who loved each other. He fed the baby but the baby always ignored him. Suddenly, their parents came to the kitchen and asked what was going on. They looked surprised and incredulous at what they had seen. Tim warned the baby if their parents were watching them. The utterance they're watching is categorized as warning in directive illocutionary act. By saying that, Tim wanted to make the baby realized that he cannot ignore his feeding because if he does it, they cannot convince their parents that they are actual brothers who love each other. As a result, the baby eats it and their parents left them after watching it.

Its illocutionary force towards the hearers' responses is as described below:

a. The point of the directive illocution of the utterance they're watching is that the speaker (Tim) gives a cue to the hearer (the baby) to do something

b. The mode of achievement of the utterance shows that the speaker warns the hearer to eat what the speaker fed to him by saying they're watching

c. The propositional content of the utterance is that the hearer eats what the speaker fed to him even though with force

d. The preparatory condition of the utterance is that the speaker presupposes that the hearer can understand what the speaker said as the warning because they have an agreement to make a plan and their plan will fail if the hearer does not do it

e. The sincerity of condition of the utterance shows that the speaker expresses his desire and confidence that the hearer will understand the warning and eat what the speaker fed to him in context to succeed their plan.

f. The degree of strength of the utterance shows the speaker's seriousness to get the hearer to do something for him. He shows threatening expression when he warned the baby so the baby will be aware and do the right ones.

The illocutionary force is successful because it fulfils all components.

\subsubsection{Adjure}


An adjuration is always solemn command which precludes the option of refusal (Vanderveken, 1990:194).

\section{Data}

Mommy: "Tim! Our hero!"

Tim : "Don't worry, Mom and Dad. I got this!"

\section{Tim : “Grab on!”}

The participants in this scene are Tim, mom, and father. Tim rescued his parents which were trapped in the mouth of fish monster by pouring a bottle of chili sauce on the fish monster's tongue. In the end, Tim was successful in his mission to rescue his parents. The speaker, here, employs the illocutionary act of directive. More specifically, his utterance is included into adjuring. The speaker wants the hearers to do something for him. His utterance is typified by the use of imperative form. Imperative sentences often appear to be missing subjects and use a verb to begin the sentence. For this case, the utterance used an exclamation mark (!) as the final punctuation.

Its illocutionary force towards the hearers' responses is as described below:

a. The point of the directive illocution of the utterance grab on! is that the speaker (Tim) attempts to adjure to the hearers (his parents) to do something

b. The mode of achievement of the utterance shows that the speaker asks the hearers to grab on his arms by saying grab on! while trying to stretch out his arms

c. The propositional content of the utterance is that the hearers hold speaker's arms

d. The preparatory condition of the utterance is that the speaker presupposes that the hearers understand what he said and hold his arms because it is the only way to rescue them from the fish monster. e. The sincerity of condition of the utterance shows that the speaker expresses and actually has a desire that the hearers hold his arms, as can be seen by his expression. He expresses his confidence and seriousness that he can help his parents.

f. The degree of strength of the utterance shows the speaker's seriousness to get responses from the hearer. It can be seen in the sincerity of condition; moreover, he uses a firm tone.

The illocutionary force is successful because it fulfils all components.

\subsubsection{Forbid}

Forbidding is the propositional negation of ordering. Thus to forbid a hearer to do something is just to order him not to do it (Vanderveken, 1990:195).

\section{Data}

Tim : "This can't be happening."

The baby: "But it is!"

Tim : "You can't stay here!"

The baby: "I can't!"

Tim : "Don't panic!"

The baby: "But it feels right!"

Tim : "I know but we have to fix this. We have to make sure you don't get fired."

The utterances in the bold forms above indicate that Tim employs the act of forbidding. Thus to forbid the hearer to do something is just to order him not to do it. Consequently, the hearer will take a particular action that is to be relaxed. Tim uses imperative form and the utterance used an exclamation mark (!) as the final punctuation. Besides, this sentence belongs to negative imperative by putting do not before the verb.

Its illocutionary force towards the hearers' responses is as described below: 
a. The point of the directive illocution of the utterancedon't panic!is that the speaker (Tim) attempts to get the hearer (the baby) to do something

b. The mode of achievement of the utterance shows that the speaker anxiously forbids the hearer to be calm down to look for the solution by saying don't panic!

c. The propositional content of the utterance is that the hearer should be calm down but he cannot be relaxed because he is afraid of being fired

d. The preparatory condition of the utterance is that the speaker presupposes that the hearer cannot be relaxed although he has forbidden him because since the beginning

e. The sincerity of condition of the utterance shows that the speaker expresses his doubt and actually has a desire that the hearer will be calm down and look for the solutions instead of being panic, as can be seen that the speaker always stares into the hearer's eyes

f. The degree of strength of the utterance shows that the speaker's seriousness to get the hearer to do something for him by screaming.

The illocutionary force is unsuccessful because it does not fulfill all components; they are the propositional content and the preparatory condition.

\section{Conclusion}

Based on the analysis and discussion above, the first point that can be drawn as conclusion is the description of types of directive illocutionary acts. In this study, there are 6 types of directive illocutionary acts; they are request, order, suggest, warn, adjure, and forbid. The purpose of requesting is to politely ask something or someone to do something. Ordering is used to ask for something to be done. The aim of suggesting is to give or mention an idea, possible plan, and action for other people to consider. Warning is performed to make someone realize the possible danger or problem especially in the future. An adjuration is always solemn command which precludes the option of refusal. Forbidding is the propositional negation of ordering.

The second point that can be drawn as conclusion is that the illocutionary force of directive illocutionary act has the directive point that is to try to get the hearer to do things; the mode of achievement determines how its point must be achieved on the propositional content in a successful performance of an act with that force; the propositional content represents a future course of action of the hearer; the preparatory condition that the hearer can carry out that action; the sincerity condition that the speaker desires or wants the hearer to carry it out; and the degree of strength; two speech acts might be the same along other dimensions, but express psychological states that differ from one another in the dimension of strength. Illocutionary force will be considered successful or felicitous if it fulfils all components.

\section{References}

Bach, Kent. 1994. Meaning and Communication [Internet]. Encyclopedia of Philosophy, Routledge. Available from: http://userwww.sfsu.edu/ kbach/Bac h.Meaning\&Communication.pdf. [Accessed 25 May 2017]

The Boss Baby.(2017).DreamWorks Animation, United States, 31 March, [Video: HD] Available from: https://moviescouch.info/movie/theboss-baby-2017-movie-free- 
download-hd-720p-bluray/

[Accessed 25 January 2018].

Vanderveken, Daniel 1990. Meaning and Speech Acts vol 1 Principles of Language Use. Cambridge University, Cambridge.

Yule, George. 1996. Pragmatics. Oxford University Press, Oxford. 